\title{
4 Archives and the duty to remember
}

Throughout the world, memory has become a central cultural and political issue in our contemporary societies (Waldman, 2006). Archives have been swept along by the wave with thought rarely being given to the implications involved (Millar, 2006). Memory policies, or to be more accurate, policies for dealing with the past, are not the same thing as archival policies. Memory policies tend to be produced in the short term, whereas most archival policies are long term, often designed for stability to guarantee the trustworthiness of records, which need to be sustainable and neutral for credibility and evidential value reasons. There are, however, a number of authors who would have archivists reconsider the whole concept of memory,

ponder not only on how archives keep records of the past but also how, in their discourse and practices, they help to preserve a certain concept of what "the past" means. Archivists are asked to entertain the possibility that multiple perspectives are permissible of what "the past" might mean in the context of archival practice.

(Brothman, 2001)

Much of the confusion has been created by the fact that the new archival institutions set up to manage fonds that are more directly linked with human rights violations have frequently morphed into Memory Institutes or Centres. The links created, as a result, between archives and institutions set up for the purpose of harnessing public memory policies have cast doubts over the credibility of archives, especially when memory policies are known to have undergone a complete political about-turn. The questions all this begs are illustrated in Part 2, Chapter 9 by José M. Faraldo (on former Communist regimes in Central and Eastern Europe) and in Part 2, Chapter 13 by Ramón Alberch i Fugueras (on Colombia).

The problem of archives and memory is, however, nothing new in our profession. Much has been written on the subject and some of the insights offered are both thought-provoking and compelling. Excellent examples may be found in Barbara Craig's review essay (2002) on some of the major writings of historians, sociologists or philosophers, who have addressed 
the issue of memory and its pertinence to archives. While there may be major differences between these two concepts, it remains true to say that almost all archiving professionals have had the satisfaction, at some point in their careers, of comparing archives and memory by using the metaphor of archives as collective memory for discussing the social and cultural role of archives in our societies, by comparison with individual memory in our personal lives (Foote, 1990). It goes without saying that memory and archives are two different phenomena. Their apparent commonalities appear to be, to some extent, associated with the use of these two terms in computer science, where the words "internal and external memory" refer to places where documents are stored. The problem is that, in our everyday lives, human memory and computer memory have very different connotations, especially with regard to the ability to forget or deliberately suppress. Archives, as institutions, are not allowed to forget or suppress information of historical value, because this would harm possibilities of ever being able to analyse the facts in full.

Records and archives are not in themselves "memories", but only touchstones upon which memories may be retrieved, preserved and articulated. Laura Millar (2006) reminds us that records and archives are among countless different devices used in the process of transforming individual memories into collective remembering. Records, along with stories, artefacts, songs, rituals, traditions and myriad other non-documentary touchstones, are used to shape memories into narratives and to transform information and recollection from the individual to the collective. Nevertheless, as tools for retrieving or creating collective memory, archives play a major role in the struggle of man against forgetting and in the search for the truth. This has been recognised by a number of organizations, not least those for the defence of human rights. For archives are not just tools for memory but antidotes to forgetting (Millar, 2006).

Colombia's National Centre for Historical Memory, which was set up in 2011, is a useful reference, because in its mission statement, it clearly mentions archives as a tool for building plural memories and for securing the truth. The Centre is a public entity attached to the Department for Social Prosperity (Departmento Administrativo para la Prosperidad Social DPS), the purpose of which is to collect and retrieve all documentary material, especially oral and other personal testimonies connected with the violations mentioned in Article 147 of the Victims and Land Restitution Law (Ley de Víctimas y Restitución de Tierras). The information collected is to be made available to interested parties, researchers and the population in general. The Centre's role is to contribute towards providing full reparation and ensuring that the victims themselves and society in general enjoy the right to know the truth. It also has the role of enabling the State to fulfil its duty of remembrance to the victims of violations during the Colombian conflict in order to achieve the ultimate goal of peace, democracy and reconciliation. 


\section{Archives and the duty to remember}

In political transitions from totalitarian, repressive or dictatorial regimes towards democracy and in efforts to rise above domestic armed conflict, Memory institutes, centres or Archives are bound to be a recurrent feature of the process as they try to combine creating memory with the combat against oblivion and the search for truth. The first decade of the 21st century has seen major changes in legislation and the creation of institutions to manage archives or deal with the past, for example Memory Archives and Museums. Nearly all transitional countries in Central and Eastern Europe have passed laws on the archives of the former State security services. These regulations were extremely prolific in the case of the new institutions, defining conditions for the use of records, either through standards specific to archives or through provisions governing archival fonds included in more general legislation on memory or on dealing with the past. 